\title{
EWSR1/ATF1 Fusion Protein
}

National Cancer Institute

\section{Source}

National Cancer Institute. EWSR1/ATF1 Fusion Protein. NCI Thesaurus. Code C99218.

A fusion protein encoded by the EWSR1/ATF1 fusion gene. This protein is comprised of the transactivation domain of the RNA-binding protein EWS followed by the DNA-binding basic domain and leucine zipper dimerization domain of the cyclic AMP-dependent transcription factor ATF-1 protein. 